\title{
STUDI TENTANG SELF CONSTRUAL REMAJA ETNIS MADURA DENGAN PENDEKATAN INDIGENEOUS PSYCHOLOGY
}

\author{
Yudho Bawono \\ Program Studi Psikologi \\ Fakultas IImu Sosial dan IImu Budaya Universitas Trunojoyo Madura \\ dhobano@yahoo.co.id
}

\begin{abstract}
This study was conducted to determine the difference between selfconstrual interdependent with independent self-construal Madura adolescents. This study focuses on the approach of indigenous psychology, a scientific study of indigenous human behavior and mentality, not brought from other regions, and designed for its own people. The study involved 146 students of Trunojoyo University Madura as the subject of research and data collection is done by spreading the Self Construal Scale. Data analysis used t test: one sample $t$ test to see independent and interdependent self construal difference in whole subject, and independent sample $t$ test to know the difference of each self construal in women and men. The study found two main results. First, the results of this study indicate a very significant difference between self-construal interdependent with independent self-construal, in which Madurese adolescents have a tendency to present their self-construal interdependent. Second, the results of this study indicate that there is a significant difference between male and female selfconstrual, whereas Madurese adult males are more independent than Madurese ethnic adolescents.
\end{abstract}

Keywords: ethnic madura, indigeneous psychology, self construal

\begin{abstract}
Abstraksi. Penelitian ini dilakukan untuk mengetahui perbedaan antara self construal interdependen dengan self construal independen remaja Madura. Penelitian ini berfokus pada pendekatan indigenous psychology, yaitu suatu kajian ilmiah mengenai perilaku dan mental manusia yang bersifat pribumi, tidak dibawa dari daerah lain, dan didesain untuk masyarakatnya sendiri. Penelitian ini melibatkan 146 mahasiswa Universitas Trunojoyo Madura sebagai subjek penelitian dan pengumpulan datanya dilakukan dengan menyebarkan Skala Self Construal. Analisis data menggunakan uji t: one sample $t$ test untuk melihat perbedaan self construal independen dan interdependen pada keseluruhan subjek, dan independent sample $t$ test untuk mengetahui perbedaan masingmasing self construal pada perempuan dan laki-laki. Penelitian ini menemukan dua hasil utama. Pertama, hasil penelitian ini menunjukkan adanya perbedaan yang sangat signifikan antara self construal interdependen dengan self construal independen, di mana remaja etnis Madura memiliki kecenderungan untuk menampilkan self construal interdependennya. Kedua, hasil penelitian ini menunjukkan ada perbedaan yang signifikan antara self construal laki-laki dengan perempuan, dimana remaja laki-laki etnis Madura lebih independen dibandingkan dengan remaja etnis Madura yang perempuan.
\end{abstract}


Kata kunci : etnis madura, indigeneous psychology, self construal

\section{PENDAHULUAN}

Madura adalah nama sebuah pulau yang berada di sebelah timur laut Jawa Timur. Pulau ini luasnya kurang lebih $5.168 \mathrm{~km}^{2}$ dengan jumlah penduduk hampir 4 juta jiwa (wikipedia, 2015) Meskipun penduduknya dikenal sebagai orang yang kurang resmi,keras, tidaksopan,nada suara dalam bercakap-cakap berani dan tidak sungkan-sungkan, bahkan seringkali mendekati kurang ajar (De Jonge, 2012), namun sebenarnya orang Madura juga memiliki sifat lemah lembut sebagaimana digambarkan pada asal kata madura yang dalam Bahasa Sansekerta memiliki arti permai, indah, molek, cantik, jelita, manis, ramah tamah, lemah lembut (Mardiwarsito dalam Rifai, 2007).

Sebutan ramah tamah dan lemah lembut itu sendiri tampak pada perilaku dalam memelihara jalinan persaudaraan sejati (taretan dhibi') yang tergambar dalam ungkapan budaya"oreng dhaddhi taretan, taretan dhaddhi oreng"(orang lain bisa menjadi/dianggap sebagai saudara sendiri, sedangkan saudara sendiri bisa menjadi/dianggap sebagai orang lain). Keunikan yang muncul dari ungkapan kultural (pseudokinship) itu diwujudkan dalam bentuk perilaku aktual. Secara konkret, ucapan kultural tersebut memiliki makna bahwa kecocokan dalam menjalin persahabatan atau persaudaraan dapat dikukuhkan secara nyata dan abadi. Artinya, orang lain yang berperilaku sejalan dengan watak-dasar individu etnik
Madura dapat dengan mudah diperlakukan sebagai saudara kandungnya (pseudokinship)(Taufiqurrahman, 2006).

Orang Madura yang masih menginternalisasi ungkapan budaya tersebut menurut Markus dan Kitayama (Supradewi dan Setyaningsih, 2013) berarti memiliki self construal interdependen. Menurut Kuswanti (2007) ada perbedaan cara seseorang dalam memandang dirinya dalam hubungannya dengan orang lain. Sebagian orang memandang dirinya sebagai individu yang unik atau terpisah dari orang lain. Sebagian yang lain memandang dirinya sebagai bagian dari orang lain. Cara pandang ini disebut self construal. Tipe yang pertama dikatakan memiliki selfconstrual independen dominan, sedangkan yang kedua disebut memiliki selfconstrual interdependen dominan. Kedua dimensi self construal ini dimiliki setiap orang, namun dengan derajat yang berbeda-beda. Tingkah laku orang dengan selfconstrual independen dominan ditentukan oleh atribusi atau kemampuan dirinya sendiri. la bertujuan untuk mengekspresikan keunikan dirinya. Sedangkan tingkah laku orang dengan selfconstrual interdependen dominan dipengaruhi oleh perasaan dan tingkah lakuorang lain. Tujuan orang ini adalah untuk mempertahankan keharmonisan kelompoknya.

Dengan kata lain, menurut Markus dan Kitayama (dalam Supradewi dan Setyaningsih, 2013) 


\section{e-ISSN :2541450X}

orang dalam budaya yang berbeda memiliki penggambaran mengenai diri dan hubungannya dengan orang lain secara berbeda. Penggambaran diri ini mempengaruhi kognisi, emosi, dan motivasi seseorang. Orang Amerika dan Asia memiliki self construal yang berbeda, orang Amerika lebih memprioritaskan diri mereka tanpa tergantung dari orang lain atau memiliki self construal independence,sebaliknyaorang Asia mempertimbangkan harmoni hubungannya dengan orang lain atau memiliki self construal interdependence.

Bertolak pada uraian tersebut, saat ini perlu dikaji mengenai penggambaran orang Madura apakah masih terdapat ungkapan budaya "oreng dhaddhi taretan, taretan dhaddhi oreng"ataukah sudah mengalami pergeseran, khususnya di kalangan remaja yang beretnis Madura? Apakah self construal interdependence mereka telah bergeser menjadi self construal independence? Fenomena ini yang membuat penulis tertarik untuk melakukan penelitian dengan pendekatan indigenous psychology, yaitu suatu kajian ilmiah mengenai perilaku dan mental manusia yang bersifat pribumi, tidak dibawa dari daerah lain, dan didesain untuk masyarakatnya sendiri (Kim \& Berry, 1993) Pendekatan indigenous psychology ini mendukung pembahasan mengenai pengetahuan, keahlian, kepercayaan yang dimiliki seseorang serta mengkajinya dalam bingkai kontekstual yang ada. Teori, konsep, dan metodenya dikembangkan secara indigenous disesuaikan dengan fenomena psikologi yang
Jurnal Indigenous Vol. 1 No. 22016

kontekstual. Tujuan utama dari pendekatan indigenous psychology adalah untuk menciptakan ilmu pengetahuan yang lebih teliti, sistematis, universal yang secara teoritis maupun empiris dapat dibuktikan (Kim et. all., 2006)

Penelitian ini diajukan ingin menggambarkan dengan lebih mendalam fenomena self construal yang dimiliki para remaja beretnis Madura. Apakah self construal mereka lebih dominan interdependen atau independen? Apakah ada perbedaan self construal antara remaja etnis Madura yang laki-laki dengan remaja etnis Madura yang perempuan? Bagaimana pula pendekatan dari indigenous psychology dalam mencermati hal itu?

Berdasarkan pertannyaan penelitian tersebut tujuan penelitian ini adalah penyediaan gambaran yang menyeluruh tentang etnisitas remaja Madura dalam kaitannya dengan self construal dan pendekatan indigenous psychology.

Self construal yaitu cara individu berfikir, merasa, dan bertindak sesuai dengan orientasi nilai budaya yang diyakininya. Konsep tentang self construal diperkenalkan oleh Markus dan Kitayama pada tahun 1991. Konsep ini mulai berkembang menjadi perspektif umum dalam memprediksi dan menjelaskan perbedaan nilai budaya melalui kognisi, emosi, motivasi dan komunikasi (Siswanto, 2014).

Menurut Supratiknya (2006) self construal sejalan dengan konsep selfways yang dalam pengertiannya adalah cara berada, berfikir, merasa dan bertindak yang secara khas dimiliki dan dihayati 
e-ISSN :2541450X

oleh kelompok yang memiliki orientasi nilai budaya tertentu. Dan dalam tipologi individualistic dan kolektivistik selfways terbagi dalam dua kategori yaitu independent selfways dan interdependent selfways.

Sejalan dengan kedua macam selfways itu, ada dua kategori besar self construal, yaitu self construal independen sebagai padanan independent selfways dalam kebudayaan individualistik, serta self construal interdependen sebagai padanan interdependent selfways dalam kebudayaan kolektivistik (Supratiknya, 2006). Ciri-ciri self construa lindependen adalah keyakinan bahwa: (1) setiap pribadi secara inheren terpisah dari yang lain; (2) setiap pribadi wajib menjadi tidak tergantung pada orang lain serta menemukan dan mengekspresikan sifat-kemampuan pribadinya yang unik; (3) arah dan makna tingkah laku pribadi terutama ditentukan oleh pikiran, perasaan, dan keputusan sendiri; (4) pribadi merupakan pusat kesadaran, perasaan, penilaian, dan tindakan yang bersifat utuh, unik, dan terintegrasi; (5) motivasi dasar yang menggerakkan tingkah laku pribadi adalah dorongan untuk "mengaktualisasikan diri", "merealisasikan diri", "mengekspresikan aneka kebutuhan, hak, dan kemampuan yang bersifat unik", serta "mengembangkan aneka potensi yang khas"; dan (6) diri adalah pribadi yang otonom serta tidak tergantung.

Markus dan Kitayama (dalam Supratiknya, 2006)
Jurnal Indigenous Vol. 1 No. 22016

mengemukakan bahwa self construal independen adalah khas kebudayaan Barat serta berakar pada tradisi Cartesian tentang dualisme antara jiwa dan badan. Ciri-ciri self construal interdependen adalah keyakinan bahwa: (1) secara fundamental manusia bersifat saling terhubung atau saling tergantung; (2) setiap orang wajib menjaga dan memelihara kesalingtergantungan ini; (3) saling tergantung berarti: memandang diri sebagai bagian dari sebuah jaringan relasisosial dan mengakui bahwa tingkah laku seseorang ditentukan, tergantung, dan diarahkan oleh persepsi orang itu tentang pikiran, perasaan, dan reaksi orang-orang yang berada dalam jaringan relasiitu; (4)komponen diri yang menonjol pengaruhnya adalah komponen diri publik (publicself); (5) tingkah laku seseorang tidak ditentukan oleh dunia batinnya (innerself), melainkan oleh relasinya dengan orang lain. Menurut Markus dan Kitayama (dalam Supratiknya, 2006) self construal interdependen berakar pada tradisi filsafat monism yang memandang pribadi sebagai esensi dan tak terpisahkan dari semesta alam, serta yang lazim hidup dalam kebudayaan-kebudayaan Timur atau non-Barat. Selanjutnya Markus dan Kitayama (dalam Rufaedah, 2012) menggambarkan perbedaan independent self construal dan interdependent self construal kurang lebih sebagai berikut : 


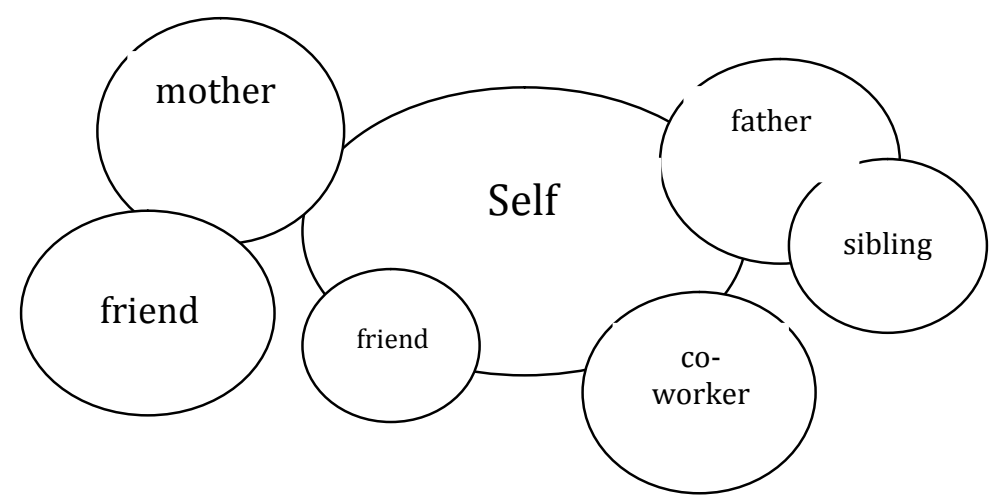

Gambar 1.

Self Construal Independen

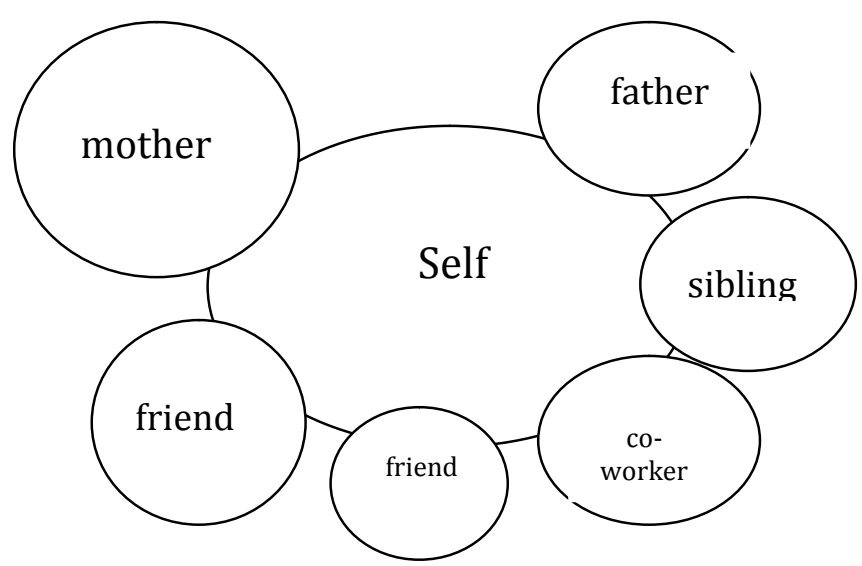

Gambar 2

Self Construal Interdependen

Di masyarakat Madura, dikenal adanya ungkapan budaya "oreng dhaddhi taretan, taretan dhaddhi oreng" (orang lain bisa menjadi/dianggap sebagai saudara sendiri, sedangkan saudara sendiri bisa menjadi/dianggap sebagai orang lain). Secara turun temurun, ungkapan budaya ini telah menginternalisasi masyarakat Madura mulai dari kanak-kanak hingga dewasa dan lanjut usia. Pemahaman inilah yang kemudian membentuk self construal interdependen di masyarakat Madura, dimana salah satu cirinya yaitu mereka memandang diri sebagai bagian dari sebuah jaringan relasi social dan mengakui bahwa perilaku seseorang ditentukan, tergantung, dan diarahkan oleh persepsi orang itu tentang pikiran, perasaan, dan reaksi orang-orang yang berada dalam jaringan relasi itu.

Namun, dengan masuknya budaya-budaya lain ke dalam wilayah Madura serta semakin 
e-ISSN :2541450X

terbukanya masyarakat Madura terhadap budaya-budaya lain tersebut, baik itu melalui pesatnya teknologi dan informasi maupun akses yang lebih mudah dengan dibangunnya jembatan Suramadu, ada kecenderungan bahwa masyarakat Madura mulai bergeser pada self construal independen yang dicirikan dengan arah dan makna perilaku pribadi terutama ditentukan oleh pikiran, perasaan, dan keputusan sendiri. Dengan demikian pemahaman tentang ungkapan budaya "oreng dhaddhi taretan, taretan dhaddhi oreng" itu bergantung pada pribadi masingmasing dan bukan merupakan perilaku yang orientasinya didasarkan pada budaya dimana dia tinggal.

Secara umum, teori-teori yang dikemukakan di atas akan sangat membantu pelaksanaan penelitian yang dilaksanakan di Madura. Dalam uraian singkat, dapat diketahui bahwa ungkapan budaya yang menyatakan bahwa orang lain bisa menjadi/dianggap sebagai saudara sendiri, sedangkan saudara sendiri bisa menjadi/dianggap sebagai orang lainakan lebih mudah dipahami jika dilihat melalui pendekatan indigenous psychology yaitu suatu kajian ilmiah mengenai perilaku dan mental manusia yang bersifat pribumi, tidak dibawa dari daerah lain, dan didesain untuk masyarakatnya sendiri.

Tidak banyak penelitian tentang self construal yang pernah dilakukan sebelumnya. Beberapa penelitian yang pernah dilakukan di Indonesia yang bisa disebutkan yaitu penelitian Kartasasmita (2007) yang meneliti hubungan self construal dengan gaya penanganan konflik. Hasil studi tersebut yaitu self construal independen berpengaruh pada gaya penanganan konflik mendominasi dan intergrasi dan interdependen berpengaruh pada gaya penanganan konflik menghindar. Tingkat pengaruhnya sebanyak $59 \%$, 4\%, dan $71 \%$.

Penelitian lain yang pernah dilakukan yaitu penelitian dari Siswanto (2014) yang ingin mengetahui perbedaan ingroup favoritism pada mahasiswa aktivis ditinjau dari konstrual diri independen-interdependen. Dari hasil penelitian menunjukkan bahwa ada perbedaan yang signifikan ingroup favoritism pada mahasiswa aktivis ditinjau dari konstrual diri independen dan interdependen, dimana konstrual diri interdependen memiliki ingroup favoritism lebih tinggi dibandingkan dengan konstrual diri independen. Individu yang cenderung memiliki konstrual diri interdependen, maka tingkat ingroup favoritism akan semakin tinggi juga. Sebaliknya, jika individu cenderung memiliki konstrual diri independen, maka ingroup favoritism semakin rendah.

Sementara penelitian self construal yang terkait dengan budaya dapat dilihat pada penelitian Rufaedah (2012) yang menemukan tiga hasil utama. Pertama, prestasi, hubungan sosial, dan keluarga adalah ranah yang menentukan subjective well being responden yang beretnis Jawa. Kedua, self construal interdependen responden yang beretnis Jawa lebih tinggi dibanding self construal independen responden yang beretnis Jawa. Hasil ini menjelaskan bahwa responden lebih menggambarkan dirinya 
e-ISSN :2541450X

sebagai pribadi yang terkait dengan orang lain. Ketiga, self construal merupakan prediktor dari subjective well being. Hasil ini menjelaskan bahwa pemaknaan diri secara keseluruhan berpengaruh terhadap kebahagiaan subjektif seseorang. Tetapi self construal interdependen kecil kontribusinya terhadap subjective well being dan tidak dapat digunakan untuk memprediksi subjective well being.

Penelitian ini didukung oleh penelitian yang dilakukan oleh Supradewi dan Setyaningsih (2013) yang menemukan bahwa self construal interdependen remaja Jawa masih lebih tinggi dibandingkan dengan self construal independennya $(\mathrm{t}=142,780, \mathrm{df}=269$, p 0,05). Perbedaan antara laki-laki dan perempuan juga terlihat pada self construal interdependen. Perempuan lebih interdependen dibandingkan laki-laki $(\mathrm{t}=-2,386$, $d f=269$, p 0,05). Sebaliknya, tidak terdapat perbedaan yang signifikan pada self construal independen pada kedua jenis kelamin.

Belum adanya penelitian yang dilakukan di Madura dengan melibatkan mahasiswa sebagai representasi dari remaja beretnis Madura mendorong peneliti untuk melakukan penelitian tentang self construal pada remaja beretnis Madura ditinjau dari pendekatan indigenous psychology. Melalui pendekatan indigenous psychology ini, penelitian akan lebih menitikberatkan pada kajian ilmiah mengenai perilaku dan mental manusia yang bersifat pribumi, tidak dibawa dari daerah lain, dan didesain untuk masyarakatnya sendiri.
Jurnal Indigenous Vol. 1 No. 22016

\section{METODE PENELITIAN}

Penelitian ini menggunakan penelitian deskriptif yaitu suatu bentuk penelitian yang ditujukan untuk mendeskripsikan fenomenafenomena yang ada, baik fenomena alamiah maupun fenomena buatan manusia. Fenomena itu bisa berupa bentuk, aktivitas, karakteristik, perubahan, hubungan, kesamaan, dan perbedaan antara fenomena yang satu dengan fenomena lainnya (Sukmadinata, 2006). Fenomena disajikan secara apa adanya, hasil penelitiannya diuraikan secara jelas dan gamblang tanpa manipulasi. Oleh karena itu penelitian ini tidak ada hipotesis tetapi pertanyaan penelitian. Lokasi penelitian berada di Universitas Trunojoyo Madura. Subjek penelitian dipilih sesuai dengan kriteria sebagai berikut: merasa sebagai orang Madura, berasal dari keturunan Madura (bapak dan ibu beretnis Madura), dan besar atau menghabiskan waktu di Madura. Jumlah keseluruhan subjek penelitian adalah 146 mahasiswa yang terdiri dari 73 mahasiswa dan 73 mahasiswi yang diambil secara incidental sampling.

Pengukuran self construal dilakukan dengan menggunakan skala self construal yang disusun oleh Singelis pada tahun 1994 dan telah diadaptasi oleh Rufaedah (2012). Skala ini terdiri dari 24 item yang terbagi dua, masing-masing 12 item untuk mengukur self construal independence (contoh: saya lebih suka mengatakan "tidak" secara langsung daripada beresiko disalahpahami) dan self construal interdependence (contoh: saya sering memiliki perasaan bahwa hubungan saya dengan orang lain 
e-ISSN :2541450X

lebih penting daripada diri saya sendiri).

Analisis data menggunakan uji t: one sample $t$ test untuk melihat perbedaan self construal independen dan interdependen pada keseluruhan subjek, dan independent sample $t$ test untuk mengetahui perbedaan masingmasing self construal pada perempuan dan laki-laki. Penelitian ini bersifat survei sehingga peneliti tidak mengajukan hipotesis untuk diuji.

\section{HASIL DAN PEMBAHASAN}

Berdasarkan uji One Sample tTest hasil penelitian menunjukkan adanya perbedaan yang sangat signifikan antara self construal interdependen dengan self construal independen. Subjek penelitian memiliki kecenderungan
Jurnal Indigenous Vol. 1 No. 22016

menampilkan self construal interdependen. Mereka lebih menggambarkan dirinya sebagai pribadi yang terikat dengan orang lain. Namun perlu digaris bawahi di sini bahwa selisih mean antar self construal cukup kecil. Hal ini menandakan penggambaran diri subjek tidak secara ekstrem mengarah ke self construal tertentu.

One-Sample Statistics

\begin{tabular}{|l|l|l|l|l|}
\hline & $\mathrm{N}$ & Mean & $\begin{array}{l}\text { Std. } \\
\text { Deviation }\end{array}$ & Std. Error Mean \\
\hline $\begin{array}{l}\text { Interdepende } \\
\mathrm{nt}\end{array}$ & 146 & 47,719 & 3,9978 &, 3309 \\
\hline
\end{tabular}

Pada variabel interdependen diperoleh nilai rata=rata sebesar 47,719

One-Sample Test

\begin{tabular}{|c|c|c|c|c|c|c|}
\hline & \multicolumn{6}{|c|}{ Test Value $=0$} \\
\hline & \multirow[b]{2}{*}{$\mathrm{T}$} & \multirow[b]{2}{*}{ Df } & \multirow{2}{*}{$\begin{array}{l}\text { Sig. } \\
\text { tailed) }\end{array}$} & \multirow{2}{*}{$\begin{array}{l}\text { Mean } \\
\text { Difference }\end{array}$} & \multicolumn{2}{|c|}{$\begin{array}{ll}95 \% & \text { Confidence } \\
\text { Interval of the } \\
\text { Difference }\end{array}$} \\
\hline & & & & & Lower & Upper \\
\hline $\begin{array}{l}\text { Interdepend } \\
\text { ent }\end{array}$ & $\begin{array}{l}144,22 \\
6\end{array}$ & 145 & ,000 & 47,7192 & 47,065 & 48,373 \\
\hline
\end{tabular}

Terlihat bahwa t hitung adalah 144 dengan probabilitas 0,000. Angka probabilitas menjadi $=0,000 / 2=0$ dan $0>0,025$ 


\begin{tabular}{|l|l|l|l|ll|}
\hline & N & Mean & $\begin{array}{l}\text { Std. } \\
\text { Deviation }\end{array}$ & $\begin{array}{l}\text { Std. } \\
\text { Mean }\end{array}$ & Error \\
\hline Independen & 146 & 47,637 & 4,0986 &, 3392 & \\
\hline
\end{tabular}

Pada variabel independent diperoleh nilai rata-rata sebesar 47,637

One-Sample Test

\begin{tabular}{|c|c|c|c|c|c|c|}
\hline & \multicolumn{6}{|c|}{ Test Value $=0$} \\
\hline & \multirow[b]{2}{*}{$t$} & \multirow[b]{2}{*}{ Df } & \multirow{2}{*}{$\begin{array}{l}\text { Sig. } \\
\text { tailed) }\end{array}$} & \multirow{2}{*}{$\begin{array}{l}\text { Mean } \\
\text { Difference }\end{array}$} & \multicolumn{2}{|c|}{\begin{tabular}{|lrr}
$95 \%$ & \multicolumn{2}{c}{ Confidence } \\
Interval of the \\
Difference
\end{tabular}} \\
\hline & & & & & Lower & Upper \\
\hline $\begin{array}{l}\text { Independ } \\
\text { en }\end{array}$ & $\begin{array}{l}140,43 \\
9\end{array}$ & 145 & , 000 & 47,6370 & 46,967 & 48,307 \\
\hline
\end{tabular}

Terlihat bahwa $t$ hitung adalah 140,439 dengan probabilitas 0,000 . Angka probabilitas menjadi $=$ $0,000 / 2=0$ dan $0>0,025$. Pada prinsipnya, tujuan uji dua sampel adalah ingin mengetahui apakah ada perbedaan rata-rata (mean) antara dua populasi, dengan melihat ratarata dua sampelnya. Pada penelitian ini, uji independent sample $t$ test digunakan untuk mengetahui perbedaan masing-masing self dengan perempuan, dimana perempuan lebih interdependen dibandingkan dengan laki-laki. Secara umum dapat dikatakan bahwa terdapat perbedaan self construal antara remaja perempuan dengan remaja laki-laki di mana self construal remaja perempuan lebih tinggi diandingkan dengan remaja laki-laki. construal pada perempuan dan lakilaki. Hasil penelitian ini menunjukkan bahwa ada perbedaan yang signifikan antara self construal lakilaki dengan perempuan, di mana laki-laki lebih independen dibanding perempuan, meskipun selisih mean antar self construal independen-nya cukup kecil. Hasil penelitian ini juga menunjukkan adanya perbedaan yang signifikan antara self construal interdependen antara laki-laki 
Independent Samples Test

\begin{tabular}{|c|c|c|c|c|c|c|c|c|c|}
\hline & \multicolumn{2}{|c|}{$\begin{array}{l}\text { Levene' } \\
\text { s Testfor } \\
\text { Equality } \\
\text { of } \\
\text { Varianc } \\
\text { es }\end{array}$} & \multicolumn{7}{|c|}{ t-test for Equality of Means } \\
\hline & \multirow[b]{2}{*}{$\mathrm{F}$} & \multirow[b]{2}{*}{$\begin{array}{l}\mathrm{Si} \\
\mathrm{g} .\end{array}$} & \multirow[b]{2}{*}{ T } & \multirow[b]{2}{*}{ df } & \multirow{2}{*}{$\begin{array}{l}\text { Sig. } \\
(2- \\
\text { taile } \\
\text { d) }\end{array}$} & \multirow{2}{*}{$\begin{array}{l}\text { Mean } \\
\text { Differe } \\
\text { nce }\end{array}$} & \multirow{2}{*}{$\begin{array}{c}\text { Std. } \\
\text { Error } \\
\text { Differe } \\
\text { nce }\end{array}$} & \multicolumn{2}{|c|}{$\begin{array}{l}95 \% \text { Confidence } \\
\text { Interval of the } \\
\text { Difference }\end{array}$} \\
\hline & & & & & & & & $\begin{array}{c}\text { Lowe } \\
r\end{array}$ & Upper \\
\hline $\begin{array}{cc}\text { Inter } & \text { Equal } \\
\text { dep } & \text { varianc } \\
\text { end } & \text { es } \\
\text { ent } & \text { assum } \\
& \text { es } \\
& \text { Equal } \\
& \text { varianc } \\
& \text { es not } \\
& \text { assum } \\
& \text { es }\end{array}$ & $\begin{array}{l}1,2 \\
54\end{array}$ & $\begin{array}{c}, 26 \\
5\end{array}$ & $\begin{array}{c} \\
- \\
1,155\end{array}$ & $\begin{array}{l}140 \\
178\end{array}$ & 250 &,- 7671 & ,6642 & $\begin{array}{c}- \\
2,07 \\
99 \\
\\
- \\
2,08 \\
02\end{array}$ & ,5457 \\
\hline $\begin{array}{cc}\text { Inde } & \text { Equal } \\
\text { pen } & \text { varianc } \\
\text { den } & \text { es } \\
& \text { assum } \\
& \text { es } \\
& \text { Equal } \\
& \text { varianc } \\
& \text { es not } \\
& \text { assum } \\
\text { es }\end{array}$ & $\begin{array}{l}1,1 \\
43\end{array}$ & $\begin{array}{c}, 28 \\
7\end{array}$ & 100 & $\begin{array}{c}141, \\
191\end{array}$ & 920 & ,0685 & 6830 & $\begin{array}{c}1,28 \\
15\end{array}$ & 1,4187 \\
\hline
\end{tabular}

Group Statistics

\begin{tabular}{|c|c|c|c|c|c|}
\hline & Gender & $\mathrm{N}$ & Mean & $\begin{array}{c}\text { Std. } \\
\text { Deviation }\end{array}$ & $\begin{array}{c}\text { Std. Error } \\
\text { Mean }\end{array}$ \\
\hline S.C & Laki-laki & 73 & 46,959 & 4,2211 &, 4940 \\
& Perempuan & 73 & 48,548 & 3,8839 &, 4546 \\
\hline
\end{tabular}


Hasil penelitian ini menunjukkan adanya perbedaan yang sangat signifikan antara self construal interdependen dengan self construal independen, di mana remaja etnis Madura memiliki kecenderungan untuk menampilkan self construal interdependennya. Mereka lebih menggambarkan dirinya sebagai pribadi yang terikat dengan orang lain. Hasil penelitian ini sejalan dengan pendapat yang dikemukakan oleh Markus dan Kitayama (1991) yang mengatakan bahwa self construal independen terlihat pada budaya Amerika dan kebanyakan negara di Eropa barat.Sementara self construal interdependen terlihat pada budaya Jepang dan kebanyakan negara Asia lainnya. Indonesia adalah salah satu negara yang termasuk dalam wilayah Asia. Madura sendiri merupakan nama sebuah pulau yang berada di wilayah Indonesia, khususnya berada di sebelah timur laut Jawa Timur. Pulau ini luasnya kurang lebih $5.168 \mathrm{~km}^{2}$ dengan jumlah penduduk hampir 4 juta jiwa. Meskipun penduduknya dikenal sebagai orang yang kurang resmi, keras, tidaksopan, nada suara dalam bercakap-cakap berani dan tidak sungkan-sungkan, bahkan seringkali mendekati kurang ajar (De Jonge, 2012), namun sebenarnya orang Madura juga memiliki sifat lemah lembut sebagaimana digambarkan pada asal kata madura yang dalam Bahasa Sansekerta memiliki arti permai, indah, molek, cantik, jelita, manis, ramah tamah, lemah lembut (Mardiwarsito dalam Rifai, 2007).
Sebutan ramah tamah dan lemah lembut itu sendiri tampak pada perilaku dalam memelihara jalinan persaudaraan sejati (taretan dhibi') yang tergambar dalam ungkapan budaya "oreng dhaddhi taretan, taretan dhaddhi oreng" (orang lain bisa menjadi/dianggap sebagai saudara sendiri, sedangkan saudara sendiri bisa menjadi/dianggap sebagai orang lain). Keunikan yang muncul dari ungkapan kultural (pseudo-kinship) itu diwujudkan dalam bentuk perilaku aktual. Secara konkret, ucapan kultural tersebut memiliki makna bahwa kecocokan dalam menjalin persahabatan atau persaudaraan dapat dikukuhkan secara nyata dan abadi. Artinya, orang lain yang berperilaku sejalan dengan watak-dasar individu etnik Madura dapat dengan mudah diperlakukan sebagai saudara kandungnya (pseudo-kinship)( Taufiqurrahman, 2006).

Orang Madura yang masih menginternalisasi ungkapan budaya tersebut menurut Markus dan Kitayama (dalam Supradewi dan Setyaningsih, 2013) berarti memiliki self construal interdependen. Menurut Kuswanti (2007) self construal merupakan cara seseorang dalam memandang dirinya dalam hubungannya dengan orang lain. Sebagian orang memandang dirinya sebagai individu yang unik atau terpisah dari orang lain. Sebagian yang lain memandang dirinya sebagai bagian dari orang lain. Tipe yang pertama dikatakan memiliki selfconstrual 
independen dominan, sedangkan yang kedua disebut memiliki selfconstrual interdependen dominan.Kedua dimensi self construal ini dimiliki setiap orang, namun dengan derajat yang berbeda-beda. Tingkah laku orang dengan selfconstrual independen dominan ditentukan oleh atribusi atau kemampuan dirinya sendiri. la bertujuan untuk mengekspresikan keunikan dirinya. Sedangkan tingkah laku orang dengan selfconstrual interdependen dominan dipengaruhi oleh perasaan dan tingkah laku orang lain. Tujuan orang ini adalah untuk mempertahankan keharmonisan kelompoknya.

Hasil penelitian ini juga menunjukkan bahwa ada perbedaan yang signifikan antara self construal laki-laki dengan perempuan, di mana

laki-laki lebih independen dibanding perempuan.Hasil penelitian ini ternyata sejalan dengan pendapat Takemura, dkk (Rufaedah, 2012) dalam studinya yang membandingkan perilaku independen dan interdependen dengan penggambaran diri independen dan interdependen pada mahasiswa Jepang, Asia Kanada, Eropa Kanada, dan Eropa Australia yang dihubungkannya dengan gender. Studi dari Taakemura dan kawan-kawan ini menemukan hasil bahwa laki-laki di keempat budaya yang ditelitinya lebih independen dibandingkan perempuan.

Markus dan Kitayama (dalam Supradewi dan Setyaningsih, 2013) mengungkapkan orang dalam budaya yang berbeda memiliki penggambaran mengenai diri dan

hubungannya dengan orang lain secara berbeda. Penggambaran tentang self construal interdependen dan self construal independen yang lebih dominan pada remaja etnis Madura dengan gender laki-laki menunjukkan adanya pendekatan indigenous psychology, yaitu suatu kajian ilmiah mengenai perilaku dan mental manusia yang bersifat pribumi, tidak dibawa dari daerah lain, dan didesain untuk masyarakatnya sendiri (CICP, 2015)

\section{SIMPULAN}

Penelitian ini menemukan dua hasil utama.Pertama, hasil penelitian ini menunjukkan adanya perbedaan yang sangat signifikan antara self construal interdependen dengan self construal independen, di mana remaja etnis Madura memiliki kecenderungan untuk menampilkan self construal interdependennya. Remaja etnis Madura lebih menggambarkan dirinya sebagai pribadi yang terikat dengan orang lain. Ke dua, hasil penelitian ini juga menunjukkan bahwa ada perbedaan yang signifikan antara self construal laki-laki dengan perempuan, di mana remaja laki-laki etnis Madura lebih independen dibandingkan dengan remaja etnis Madura yang perempuan. Bagi peneliti selanjutnya yang tertarik untuk melakukan penelitian yang sejenis, diharapkan dapat mengikutsertakan subjek penelitian yang lebih banyak lagi karena penelitian ini hanya mengambil sampel sebagaian wilayah dari Pulau Madura yaitu di Kabupaten Bangkalan saja, padahal Pulau Madura terdiri dari empat 
kabupaten, yaitu Bangkalan, Sumenep.

Sampang, Pamekasan, dan

\section{DAFTAR PUSTAKA}

CICP. 2015. indigenous-psychology-in-brief. Yogyakarta: UGM

De Jonge, H. 2012. Garam Kekerasan dan Aduan Sapi Esai-Esai tentang Orang Madura dan Kebudayaan Madura. Yogyakarta: LKiS

Kuswanti, A. 2007. Hubungan Antara Self-construal dan Pengenalan Ekspresi Non-verbal Emosi Bangga. Skripsi. (Tidak Diterbitkan). Jakarta:Fakultas Psikologi Unika Atma Jaya

Rufaedah, A. 2012. Hubungan antara Self Construal dan Subjective Well-Being pada Etnis Jawa. Tesis (Tidak diterbitkan). Jakarta: Fakultas Psikologi Universitas Indonesia

Singarimbun, M dan Effendi, S. 1998. Metode Penelitian Survai. Jakarta: Pustaka LP3ES

Siswanto, Y. 2014. In-group Favoritism pada Mahasiswa Aktivis ditinjau dari Konstrual Diri Independen-Interdependen. Jurnal IImiah Psikologi Terapan. Malang : Fakultas Psikologi Universitas Muhammadiyah

Sukmadinata, S. N. 2006. Metode Penelitian Pendidikan. Bandung : Remaja Rosdakarya

Supradewi, R dan Setyaningsih, R. 2013. Self Construal pada Remaja Etnis Jawa. Prosiding Seminar Nasional. Semarang : Fakultas Psikologi Universitas Islam Sultan Agung

Supratiknya, A. 2006. Konstrual diri di Kalangan Mahasiswa.Jurnal INSAN Vol.8.Surabaya : Fakultas Psikologi Universitas Airlangga

Taufiqurrahman. 2006. Islam dan Budaya Madura. Makalah. (tidak diterbitkan) Bandung :Annual Conference on Contemporary Islamic Studies

Wikipedia, 2015. Pulau madura. Diunduh tanggal 6 Januari 2015. 